\title{
Diagnostic Value of miR-1260b in Cervical Cancer: A Pilot Study
}

\author{
Jungho Kim ${ }^{1, \S, *}$, Sunyoung Park ${ }^{2, \S, * *}$ and Hyeyoung Lee $\mathrm{e}^{2, \dagger ; *}$ \\ ${ }^{I}$ Department of Clinical Laboratory Science, College of Health Sciences, \\ Catholic University of Pusan, Busan 46252, Korea \\ ${ }^{2}$ Department of Biomedical Laboratory Science, College of Health Sciences, \\ Yonsei University, Wonju, Gangwon 26493, Korea
}

\begin{abstract}
Cervical cancer is the fourth most common cancer in women, with approximately 528,000 new cases and 266,000 women dying of it per year in the world. MicroRNAs have recently been in the spotlight as potential biomarkers that regulate gene expression and are involved in tumorigenesis. In the present study, we evaluated miR-1260b as a potential biomarker for screening of cervical cancer by quantitative reverse transcription PCR. We profiled the TCGA data of miR-1260b in 307 cervical cancer tissues. Then, miR-1260b expression levels in 10 cervical cancer tissues and 10 noncancerous tissues were investigated in a pilot study. miR-1260b was found to be significantly up-regulated in cervical cancer FFPE tissues as compared to those in cervical normal FFPE tissues $(P=0.006)$. The mean expression level of miR-1260b in late-stage (IIB-IVB) was higher than in those with early-stage (IA-IIA). Furthermore, high miR-1260b was found to be associated with high hTERT and Ki-67 mRNA expression, which are representative of tumor prognosis. The results of the pilot study suggest that miR-1260b may be used as a novel biomarker for improving the diagnosis of cervical cancer.
\end{abstract}

Key Words: Cervical cancer, miR-1260b, RT-qPCR

\section{INTRODUCTION}

Cervical cancer is the fourth leading cause of death worldwide in women after breast cancer, colon cancer, and lung cancer (Torre et al., 2015). According to the World Health Organization (WHO) report, about 528,000 new cases of cervical cancer are recorded globally, and 266,000 women die of it each year (McGuire, 2016). Risk factors of cervical cancer include human papillomavirus (HPV) infection, promiscuous sex, long-term use of hormonal contraceptives, sexually transmitted disease (STD) infection, and smoking (Burd, 2003). Current methods used to diagnose cervical cancer such as cytological and histological examinations are hampered by the examiner's subjectivity, lack of necessary expertise, and low sensitivity (Committee on Practice, 2012). Recently, various molecular diagnostic methods including HPV genotype have been developed and have come into a wide use (Boone et al., 2012; Kim et al., 2015).

microRNAs are small (18-25 nucleotides) non-coding RNAs regulating gene expression by binding the 3'-UTR of the target messenger RNAs (mRNAs) (Bartel, 2004).

Received: March 2, 2020 / Revised: March 24, 2020 / Accepted: March 25, 2020

*Professor, ${ }^{* *}$ Post-Doctor.

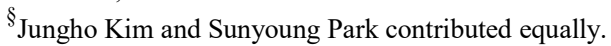

${ }^{\dagger}$ Corresponding author: Hyeyoung Lee. Department of Biomedical Laboratory Science, College of Health Sciences, Yonsei University, 1 yonseidae-gil, Wonju-si, Gangwon-do 26493, Korea.

Tel: +82-33-760-2740, Fax:+82-33-760-2561, e-mail: hyelee@yonsei.ac.kr

(C) The Korean Society for Biomedical Laboratory Sciences. All rights reserved.

(c) This is an Open Access article distributed under the terms of the Creative Commons Attribution Non-Commercial License (http://creativecommons.org/licenses/by-nc/3.0/) which permits unrestricted non-commercial use, distribution, and reproduction in any medium, provided the original work is properly cited. 
Table 1. Clinical characteristics of 20 FFPE cervical tissues

\begin{tabular}{|c|c|c|c|c|}
\hline Specimen & $\begin{array}{l}\text { HPV infection } \\
\text { status }\end{array}$ & Histology & $\begin{array}{l}\text { FIGO } \\
\text { stage }^{\text {d }}\end{array}$ & Age \\
\hline $\mathrm{C} 01$ & 16 & $\mathrm{SCC}^{\mathrm{a}}$ & IB & 65 \\
\hline $\mathrm{C} 02$ & 16 & $\mathrm{nkSCC}^{\mathrm{b}}$ & IIB & 30 \\
\hline $\mathrm{C} 03$ & 16 & SCC & IA & 39 \\
\hline $\mathrm{C} 04$ & 16 & SCC & IIA & 50 \\
\hline $\mathrm{C} 05$ & 16 & nkSCC & IIB & 55 \\
\hline $\mathrm{C} 06$ & 45 & nkSCC & IIB & 55 \\
\hline $\mathrm{C} 07$ & 16 & nkSCC & IIB & 80 \\
\hline $\mathrm{C} 08$ & 16 & SCC & IVB & 70 \\
\hline $\mathrm{C} 09$ & 16 & nkSCC & IIB & 77 \\
\hline $\mathrm{C} 10$ & 16 & $\mathrm{kSCC}^{\mathrm{c}}$ & IIA & 41 \\
\hline N01 & & & & 52 \\
\hline N02 & & & & 50 \\
\hline N03 & & & & 31 \\
\hline N04 & & & & 57 \\
\hline N05 & & & & 30 \\
\hline N06 & & & & 36 \\
\hline N07 & & & & 67 \\
\hline N08 & & & & 49 \\
\hline N09 & & & & 44 \\
\hline N10 & & & & 40 \\
\hline
\end{tabular}

${ }^{a}$ SCC, Squamous Cell Carcinoma

${ }^{\mathrm{b}} \mathrm{nkSCC}$, Nonkeratinizing Squamous Cell Carcinoma

${ }^{\mathrm{c}} \mathrm{kSCC}$, Keratinizing Squamous Cell Carcinoma

${ }^{\mathrm{d}}$ FIGO, International Federation of Gynecology and Obstetrics

Numerous previous studies have reported that microRNAs involved in tumorigenesis are potential diagnosis, prognosis and therapeutic biomarkers in various types of cancer. miRNAs have been proposed to function as tumor genes or tumor suppressors based on the inhibition of expression of tumor suppressor or oncogene, respectively (Lui et al., 2007; Hebert and De Strooper, 2009; Bouyssou et al., 2014). In recent studies, several miRNAs have been considered to be diagnostic markers of cervical cancer. The Cancer Genome Atlas (TCGA) data were provided by clinical information and genomic sequencing data such as mRNA, microRNA, and methylation. However, since there are over 10,000 to 100,000 various genomic targets, there is a lack of clinical validation of specific targets (Banister et al., 2017).

Among these several miRNAs, miR-1260b has been reported to play an important role in the tumorigenesis of renal, prostate, lung, and colon cancer cells. miR-1260b is located in human 11q21 and was first identified in human renal cancers using miRNA microarray (Hirata et al., 2013). However, the clinical relevance of miR-1260b in cervical cancer is still poorly understood. In our pilot study, miR$1260 \mathrm{~b}$ as potential biomarkers for cervical cancer were investigated using 20 formalin-fixed paraffin-embedded (FFPE) cervical tissues. In addition, we analyzed the association between the expression levels of miR-1260b and FIGO stage, the immortalization marker hTERT, and the proliferation marker Ki-67 expression.

\section{MATERIALS AND METHODS}

\section{Clinical samples}

A total of 10 FFPE cervical tissues were obtained from cervical cancer patients diagnosed with cervical cancer at Yonsei University Wonju Severance Christian Hospital, Wonju, Republic of Korea from 2010 to 2014. A total of 10 FFPE normal cervical tissues were obtained from the patients with non-cervical, benign, uterine disease (Table 1). All study participants provided written consent, and the study was approved by the institutional ethics committee at Yonsei severance hospital (approval no. CR315052).

\section{Deparaffinization of FFPE tissue and total RNA ex- traction}

For RNA extraction of FFPE cervical tissues, three to four 10 - $\mu \mathrm{m}$-thick sections were transferred to $1.5 \mathrm{~mL}$ tube each. Before extracting RNA, the paraffin was removed from the tissue sections by adding $160 \mu \mathrm{L}$ of deparaffinization solution (Qiagen, Hilden, Germany), followed by incubation for 3 min at $56^{\circ} \mathrm{C}$. Total RNA extraction was extracted according to the manufacturer's protocol (Qiagen RNeasy FFPE kit, Qiagen). Next, the concentration of the total RNA was measured with an Infinite 200 spectrophotometer (Tecan, Salzburg, Austria). Total RNA was stored at $-80^{\circ} \mathrm{C}$ until further use.

miRNA Reverse-Transcriptase (RT)- Quantitative (q) PCR analysis

TaqMan miRNA Reverse Transcription kit (Applied Bio- 
systems, Foster City, CA, USA) was used to synthesize cDNA according to the manufacturer's instructions. Reverse transcription reactions were performed using $10 \mathrm{ng}$ of total RNA and specific reverse transcription primers (Life Technologies) for Homo sapiens (hsa)-miR-1260b and RNU6B. Reverse transcription was performed at $16^{\circ} \mathrm{C}$ for $30 \mathrm{~min}$, $42^{\circ} \mathrm{C}$ for $30 \mathrm{~min}$, and 85 for $5 \mathrm{~min}$.

After the reverse transcription, miRNA expression was quantified using the TaqMan small RNA assays (Applied Biosystems by Life Technologies) with miRNA specific primers (miR-1260b) measuring the cycle threshold $\left(\mathrm{C}_{\mathrm{T}}\right)$, the number of PCR cycles in which fluorescence exceeds the background fluorescence value. Briefly, the initiation step of PCR cycling conditions was set at $95^{\circ} \mathrm{C}$ for $10 \mathrm{~min}$, followed by an amplification step of 40 cycles at $95^{\circ} \mathrm{C}$ for $15 \mathrm{~s}$ and $60{ }^{\circ} \mathrm{C}$ for $60 \mathrm{~s}$. The samples were repeated twice, and the data were analyzed using the comparative $\Delta \mathrm{C}_{\mathrm{T}}$ method $\left(2-{ }^{\Delta \mathrm{C}}\right.$ ) with RNU6B as an endogenous control (Pfaffl et al., 2002).

\section{RT-qPCR for hTERT and Ki67 mRNA}

M-MLV reverse transcriptase kit (Invitrogen, Carlsbad, CA, USA) was used for a complementary DNA (cDNA) synthesis. Briefly, $0.25 \mu \mathrm{g}$ random hexamers, $1 \mu \mathrm{L} 10 \mathrm{Mm}$ $\mathrm{dNTP}$ mix, and $5 \mu \mathrm{L}$ DEPC-treated water, and $10 \mu \mathrm{L}$ total RNA were mixed. Then the mixture was incubated at $65^{\circ} \mathrm{C}$ for $5 \mathrm{~min}$ and quickly cooled on ice. Next, $4 \mu \mathrm{L}$ of $5 \times$ buffer, $2 \mu \mathrm{L}$ of $0.1 \mathrm{M}$ dithiothreitol (DTT) and $1 \mu \mathrm{L}$ of $200 \mathrm{U}$ Murine Molony Leukemia Virus Reverse Transcriptase (MMLV-RT) were added to the first mix. cDNA synthesis was performed at $25^{\circ} \mathrm{C}$ for $10 \mathrm{~min}$, at $37^{\circ} \mathrm{C}$ for $50 \mathrm{~min}$, and at $70{ }^{\circ} \mathrm{C}$ for $15 \mathrm{~min}$.

As described by Kim et al., hTERT and Ki67 mRNA expression in FFPE cervical tissues was assessed via a RTqPCR TaqMan assay and the CFX-96 real-time PCR system (Bio-Rad, Hercules, CA, USA) for thermal cycling and fluorescence detection. Real-time PCR amplification for hTERT and Ki67 mRNA was performed in a reaction mix containing $10 \mu \mathrm{L}$ of $2 \times$ Thunderbird probe qPCR mix (Toyobo, Osaka, Japan), $3 \mu \mathrm{L}$ of primer and TaqMan probe mixture, $2 \mu \mathrm{L}$ of template cDNA, and distilled water (D.W) to the final volume of $20 \mu \mathrm{L}$ per sample. Positive and nega- tive controls were included throughout the procedure. The used PCR cycling conditions were $95^{\circ} \mathrm{C}$ for $3 \mathrm{~min}$, followed by 41 cycles of $95^{\circ} \mathrm{C}$ for $3 \mathrm{~s}$, and $55^{\circ} \mathrm{C}$ for $30 \mathrm{~s}$. The samples were repeated twice, and the data were analyzed using the comparative $\Delta \mathrm{C}_{\mathrm{T}}$ method $\left(2-{ }_{\mathrm{T}}^{\Delta \mathrm{C}}\right)$ with glyceraldehyde3-phosphate dehydrogenase (GAPDH) as an endogenous control.

\section{Statistical analyses}

Statistical analyses were performed using GraphPad Prism software version 6 (GraphPad, LaJolla, CA, USA). Student's $t$-test, 95\% confidence interval (CI), and ROC curve were used to evaluate the statistical significance of the results.

\section{RESULTS}

miR-1260b expression levels in cervical cancer and normal tissues

First, we investigated TCGA data of miR-1260b in 307 cervical cancer tissues and paired 3 normal tissues. The results showed the up-regulation in cervical cancer tissues. However, the normal tissue was rare in the TCGA data, and we profiled the expression levels of miR-1260b in cervical cancer, ten cervical cancer tissues and ten normal tissues by RT-qPCR (Fig. 1). The results showed that the expression levels of miR-1260b were significantly higher in cervical cancer tissues as compared to those in cervical normal tissues $(P=0.006$; Fig. 1B). In order to investigate cut-off values for discriminating cervical cancer from normal tissues, the expression level of miR-1260b in cervical cancer and normal tissues was analyzed using a ROC curve. At the optimal cut-off point, the area under the curve (AUC) of miR-1260b was $0.850(P=0.008 ; 95 \%$ confidence interval $(\mathrm{CI}), 0663 \sim$ 1.037; Fig. 1C)

\section{miR-1260b expression according to FIGO stage}

To explore the association between miR-1260b expression and stages, we analyzed the expression levels of miR-1260b in FIGO stages. There was a difference between the miR$1260 \mathrm{~b}$ expression level of early-stage (IA-IIA) and late-stage (IIB-IVB) (Table 2). Specifically, the mean expression levels of miR-1260b were $13.20 \pm 18.69$ (mean \pm S.D) in stage 
A

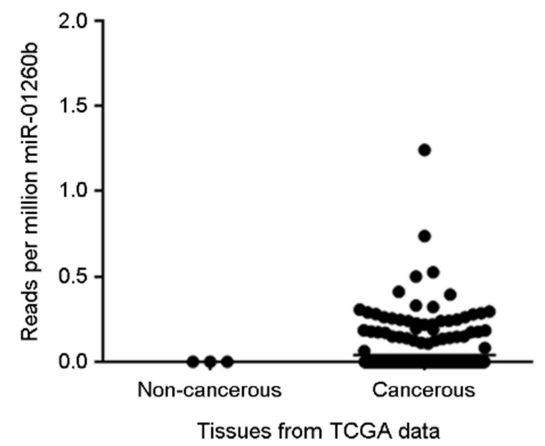

B

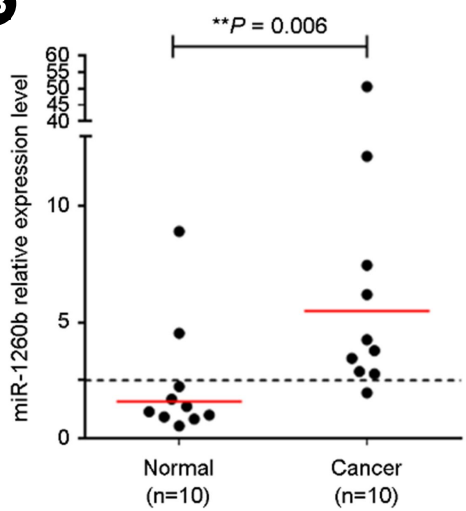

C

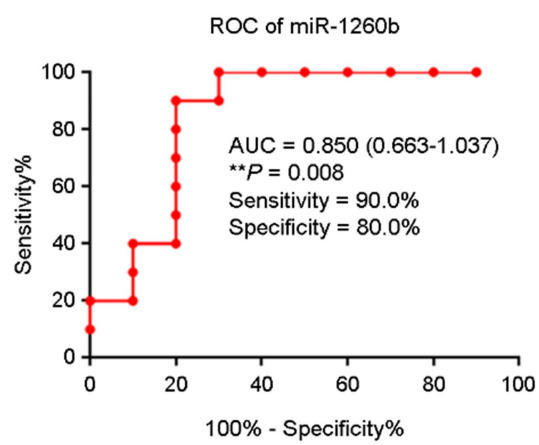

Fig. 1. miR-1260b expression of cervical cancer and normal FFPE tissues and ROC analysis. (A) The expression level of miR-1260b was higher in cervical cancer patients than in healthy controls; (B) The miR-1260b expression level in 10 FFPE cervical cancer tissues significantly differed from the one observed in 10 FFPE normal cervical tissues $(P=0.006) ;(\mathrm{C})$ The results of the receiver operator characteristic curve (ROC) analysis showed that miR-1260b had an area under the ROC curve (AUC) value of $0.850(P=0.008)$.

Table 2. miR-1260b expression according to FIGO stage

\begin{tabular}{lc}
\hline \hline \multicolumn{1}{c}{ FIGO stage } & miR-1260b expression (Mean \pm S.D) \\
\hline IA-IIA & $4.06 \pm 1.48$ \\
IIB-IVB & $13.20 \pm 18.69$ \\
\hline
\end{tabular}

IIB-IVB and $4.06 \pm 1.48$ (mean \pm S.D) in stage IA-IIA.

\section{miR-1260b expression according to hTERT and Ki67}

Subsequently, to investigate the association between miR$1260 \mathrm{~b}$ expression and tumorigenesis, we analyzed miR$1260 \mathrm{~b}$ expression according to the immortalization marker hTERT and the proliferation marker Ki-67 expression. The cases were divided into two groups according to the expression level of hTERT (high hTERT vs. low hTERT) and Ki-67 (high Ki67 vs. low Ki-67) based on the median of ex pression levels, respectively. For hTERT mRNA expression, the mean expression level of miR-1260b in high hTERT was higher than in low hTERT $(13.14 \pm 21.05$ vs. 5.97 \pm 3.61 , respectively). Similarly, the mean expression level of miR1260b in high Ki-67 was higher than in low Ki-67 (13.30 vs 5.81, respectively; Table 3).

\section{DISCUSSION}

In this pilot study, we investigated miR-1260b expression
Table 3. miR-1260b expression according to the hTERT and Ki-67 mRNA expression levels

\begin{tabular}{llc}
\hline \hline & Expression & $\begin{array}{c}\text { miR-1260b expression } \\
\text { (Mean } \pm \text { S.D) }\end{array}$ \\
\hline hTERT & & \\
& Low & $5.97 \pm 3.61$ \\
& High & $13.14 \pm 21.05$ \\
Ki67 & & \\
& Low & $5.81 \pm 4.02$ \\
& High & $13.30 \pm 20.91$ \\
\hline
\end{tabular}

levels in FFPE cervical cancer and normal tissues using RT-qPCR to identify a potential biomarker for cervical cancer. In previous research, miR-1260b was found to be highly expressed in renal carcinoma and to promote cell proliferation and invasion in renal carcinoma. Furthermore, genistein was found to inhibit Wnt-signaling by regulating miR-1260b expression in renal cancer cells (Hirata et al., 2013). In addition, genistein was reported to have anti-tumor effects through the down-regulation of miR-1260b targeting SRRP1 and Smad4 genes in prostate cells (Hirata et al., 2014). The expression of miR-1260b in non-small cell lung cancer tissues was reported to be higher than that of adjacent tissues, and overexpression of miR-1260b was found to be associated with lymph node metastasis (Xu et al., 2015). However, none of the previous studies has explored the diagnostic value of miR-1260b in cervical cancer. 
The results of our pilot study showed that the expression levels of miR-1260b were significantly higher in cervical cancer tissues as compared to those in cervical normal tissues $(P=0.006)$, suggesting that the miR-1260b plays an important role in tumorigenesis. The cut-off value of miR$1260 \mathrm{~b}$ was 2.51 for optimal sensitivity and specificity. The sensitivity of miR-1260b was $90 \%(95 \% \mathrm{CI}=55.50 \%$ to $99.75 \%$ ), while the specificity was $80 \%(95 \% \mathrm{CI}=44.39 \%$ to $97.48 \%$ ). Positive predictive value (PPV) of miR-1260b was $80 \%(95 \% \mathrm{CI}=44.39 \%$ to $97.48 \%)$, while the negative predictive value (NPV) was $80 \%(95 \% \mathrm{CI}=44.39 \%$ to $97.48 \%)$. The value of AUC was $0.85(95 \% \mathrm{CI}=0.66$ to 1.04 , $P=0.008)$.

Liu et al. explored the diagnostic potential of a panel of miRs using RT-qPCR in 582 cervical cancer patients and 145 control individuals. The levels of miR-20a, miR-92a, miR-141, miR-183, miR-210, and miR-944 were higher in cancer patients than in healthy controls. In addition, miR-20a, miR-92a, miR-141, miR-183, miR-210, and miR-944 can help differentiate between cervical cancer and healthy controls with AUC of $0.822,0.659,0.942,0.785,0.751$, and 0.677 in ROC analysis, respectively (Liu et al., 2018). The sensitivity and specificity of miR-1260b were comparable to those of other miRs for the cervical cancer diagnostic method.

We further examined the relationship between miR-1260b expression levels and FIGO stages, hTERT mRNA expression, Ki-67 mRNA expression. The mean expression level of miR-1260b in late-stage (IIB-IVB) was found to be higher than in those with early-stage (IA-IIA). Furthermore, miR$1260 \mathrm{~b}$ in high hTERT mRNA expression group and Ki-67 mRNA expression group showed a higher expression as compared to those in low hTERT mRNA expression group and Ki-67 mRNA expression group, respectively (Ross and Hall, 1995; Blasco and Hahn, 2003; Park et al., 2018). Taken together, the results suggest that miR-1260b is a potential diagnostic biomarker for cervical cancer.

The present study has several limitations. First, all cervical FFPE tissues were collected from a single hospital, and the number of the samples was small. Therefore, more tests for miR-1260b with a larger number of patients in multi-center settings would be needed to replicate our findings. Further research to investigate the relationship between clinical parameters is also necessary.

In conclusion, the results of the pilot study showed miR-1260b is up-regulated in cervical cancer FFPE tissues The high expression of miR-1260b was found to be closely related to late-stage, high expression of hTERT mRNA, Ki67 mRNA, suggesting that miR-1260b may be an oncogene in cervical cancer. miR-1260b may also potentially serve as a screening biomarker for cervical cancer.

\section{ACKNOWLEDGEMENT}

None.

\section{CONFLICT OF INTEREST}

The authors have no conflicts of interest with regards to this study.

\section{REFERENCES}

Banister CE, Liu C, Pirisi L, Creek KE, Buckhaults PJ. "Identification and characterization of HPV-independent cervical cancers". Oncotarget. 2017. 8: 13375-13386.

Bartel DP. "MicroRNAs: genomics, biogenesis, mechanism, and function". Cell. 2004. 116: 281-297.

Blasco MA, Hahn WC. "Evolving views of telomerase and cancer". Trends Cell Biol. 2003. 13: 289-294.

Boone JD, Erickson BK, Huh WK. "New insights into cervical cancer screening". J Gynecol Oncol. 2012. 23: 282-287.

Bouyssou JM, Manier S, Huynh D, Issa S, Roccaro AM, Ghobrial. IM. "Regulation of microRNAs in cancer metastasis". Biochim Biophys Acta. 2014. 1845: 255-265.

Burd EM. "Human papillomavirus and cervical cancer". Clin Microbiol Rev. 2003. 16: 1-17.

Committee on Practice BG. "ACOG Practice Bulletin Number 131: Screening for cervical cancer". Obstet Gynecol. 2012. 120: $1222-1238$

Hebert SS, De Strooper B. "Alterations of the microRNA network cause neurodegenerative disease". Trends Neurosci. 2009. 32: 199-206.

Hirata H, Hinoda Y, Shahryari V, Deng G, Tanaka Y, Tabatabai ZL, Dahiya R. "Genistein downregulates onco-miR-1260b and upregulates SFRP1 and Smad4 via demethylation and histone modification in prostate cancer cells". Br J Cancer. 2014. 110: 
$1645-1654$

Hirata H, Ueno K, Nakajima K, Tabatabai ZL, Hinoda Y, Ishii N, Dahiya R. "Genistein downregulates onco-miR-1260b and inhibits Wnt-signalling in renal cancer cells". Br J Cancer. 2013. 108: 2070-2078.

Kim S, Lee I, Lee D. "Human papillomavirus prevalence and genotype distribution in normal and ASCUS specimens: comparison of a reverse blot hybridiaztion assay with a DNA chip test". Biomedical Science Letters. 2015. 21: 32-39.

Liu SS, Chan KKL, Chu DKH, Wei TN, Lau LSK, Ngu SF, Chu MMY, Tse KY, Ip PPC, Ng EKO, Cheung ANY, Ngan HYS. "Oncogenic microRNA signature for early diagnosis of cervical intraepithelial neoplasia and cancer". Mol Oncol. 2018. 12: 2009-2022.

Lui WO, Pourmand N, Patterson BK, Fire A. "Patterns of known and novel small RNAs in human cervical cancer". Cancer Res. 2007. 67: 6031-6043.

McGuire S. "World Cancer Report 2014. Geneva, Switzerland: World Health Organization, International Agency for Research on Cancer, WHO Press, 2015". Adv Nutr. 2016. 7: 418-419.

Park S, Park S, Kim J, Ahn S, Park KH, Lee H. "Assessment of
Ki-67 for predicting effective prognosis in breast cancer subtypes". Biomedical Science Letters. 2018. 24: 1-6.

Pfaffl MW, Horgan GW, Dempfle L. "Relative expression software tool (REST) for group-wise comparison and statistical analysis of relative expression results in real-time PCR". Nucleic Acids Res. 2002. 30: e36.

Ross W, Hall PA. "Ki67: from antibody to molecule to understanding?" Clin Mol Pathol. 1995. 48: M113-117.

Torre LA, Bray F, Siegel RL, Ferlay J, Lortet-Tieulent J, Jemal A. "Global cancer statistics, 2012". CA Cancer J Clin. 2015. 65: $87-108$

Xu L, Li L, Li J, Li H, Shen Q, Ping J, Ma Z, Zhong J, Dai L. "Overexpression of miR-1260b in Non-small Cell Lung Cancer is Associated with Lymph Node Metastasis". Aging Dis. 2015. 6: $478-485$

https://doi.org/10.15616/BSL.2020.26.1.8

Cite this article as: Kim J, Park S, Lee H. Diagnostic Value of miR-1260b in Cervical Cancer: A Pilot Study. Biomedical Science Letters. 2020. 26: 8-13. 